\title{
Analisis Pola Pembelian Produk Makanan Ringan Menggunakan Algoritma Apriori
}

\author{
Novri Hadinata $^{[1]}$, Kurniawan ${ }^{[2]}$ \\ Fakultas Ilmu Komputer Universitas Bina Darma ${ }^{[1],[2]}$ \\ Jl. Jenderal A. Yani No. 3 Palembang, Sumatera Selatan, Indonesia \\ novri_hadinata@binadarma.ac.id ${ }^{[1]}$, kurniawan@binadarma.ac.id ${ }^{[2]}$
}

\begin{abstract}
CV. Sukses Mandiri is a private company engaged as the sole distributor of AIM biscuits originating from Surabaya and a variety of snacks (snack food products) originating from Surabaya with operating areas covering the Southern Sumatra and Bengkulu regions. The purpose of this study is to provide information to decision makers related to customer purchasing patterns of snack food products so that decision makers can determine the actions to be taken in the future. The algorithm used in this study is a priori algorithm with data mining techniques consisting of data cleaning, data integration, data selection, data transformation, mining process, and pattern evaluation. While this research method is descriptive method. From the results of the study there were 6 itemsset of goods most often bought by consumers. The items are 78003CTN (Mie Tek Tek), HHJH002CTN (Hoka-Hoka Beef Jelly Ice), JSI001CTN (Onion Chicken Hepillo), JSI002CTN (Hepillo Barbeque), JSI004 (Hepillo Roast Beef), and JSI001CTN (Onion Chicken Hepillo), JSI002CTN (Hepillo Barbeque), JSI004 (Hepillo Roasted Beef), and JSI001CTN (Onion Chicken Hepillo), JSI002CTN (Hepillo Barbeque), JSI004 (Hepillo Roasted Beef), and JSI001CTN (Wafer Kita 2 Onion) ).
\end{abstract}

Keywords: Apriori, Purchase, Data Mining, CV. Sukses Mandiri

Abstrak-CV. Sukses Mandiri merupakan perusahaan swasta yang bergerak sebagai distributor tunggal biskuit AIM yang berasal dari Surabaya dan berbagai macam snack (produk makanan ringan) yang berasal dari Surabaya dengan daerah operasinya meliputi wilayah Sumatera Bagian Selatan dan Bengkulu. Tujuan dalam penelitian ini yaitu memberikan informasi kepada pihak pengambil keputusan terkait dengan pola pembelian pelanggan terhadap produk makanan ringan sehingga dalam pengambil keputusan dapat menentukan tindakan yang akan dilakukan dikemudian hari. Algoritma yang digunakan dalam penelitian ini yaitu algoritma apriori dengan teknik data mining yang terdiri dari data cleaning, data integration, data selection, data transformation, Proses mining, dan pattern evaluation. Sedangkan metode penelitian ini adalah metode deskriptif. Dari hasil penelitian terdapat 6 itemset barang yang paling sering dibeli oleh konsumen. Adapun item barang tersebut adalah 78003CTN (Mie Tek-Tek), HHJH002CTN (Hoka-Hoka Jelly Es Potong), JSI001CTN (Hepillo Ayam Bawang), JSI002CTN (Hepillo Barbeque), JSI004 (Hepillo Sapi Panggang), dan SPJ065CTN (Wafer Kita 2 Rasa).

Kata Kunci: Algoritma Apriori, Pembelian, Data mining, CV. Sukses Mandiri

\section{PENDAhULUAN}

Perkembangan industri makanan dan minuman di Indonesia menjadi salah satu sektor terbaik sebagai penunjang pertumbuhan manufaktur dan ekonomi nasional[1] serta industri ini seperti halnya industri biskuit yang tidak terganggu oleh dampak krisis ekonomi[2] bahkan dari tahun ke tahun devisa yang diperoleh dari ekspor biskuit semakin besar. Data Kementerian Perindustrian RI mencatat bahwa industri makanan dan minuman telah memberikan 34,95\% dari Produk Domestik Bruto (PDB) non-migas pada triwulan III di tahun 2017[3].

CV. Sukses Mandiri merupakan perusahaan swasta yang bergerak sebagai distributor tunggal biskuit AIM yang berasal dari Surabaya dan berbagai macam makanan ringan yang berasal dari Surabaya. Pada mulanya pemegang distributor tunggalnya adalah CV. Sejahtera Mandiri dengan daerah operasinya meliputi wilayah Sumatera Bagian Selatan dan Bengkulu. Tetapi mulai bulan April 2010 pemegang hak sebagai distributor berpindah kepada CV. Sukses Mandiri. Hasil penjualan yang dilakukan perusahaan menunjukkan adanya peningkatan pembelian baik dari agen maupun pertokoan (yang selanjutnya disebut pelanggan) yang menjual makanan ringan. Proses pembelian yang dilakukan pelanggan biasanya melakukan permintaan terlebih dahulu berdasarkan persediaan yang ada di perusahaan. Namun terkadang persediaan yang diinginkan pelanggan tersebut tidak mencukupi atau kurang persediaannya sehingga harus melakukan stok ulang terhadap produk yang ada. Sedangkan produk-produk yang kurang diminati pelanggan melebihi dari stok yang ada digudang bahkan masa kadaluarsa (expired date) sudah melebihi dari waktu yang ditentukan. Dampak sangat buruk untuk keberhasilan dan kelancaran transaksi jual beli akibat dari kekurangan persediaan barang pada suatu toko atau perusahaan, penyebab terjadinya kekosongan persediaan tidak lain adalah tidak adanya informasi yang diterima oleh supplier penyetok barang terhadap penyampaian informasi oleh perusahaan secara dini[4]. Hal ini juga sangatlah mempengaruhi pihak pengambil keputusan untuk mengambil tindakan berdasarkan permintaan pelanggan, sehingga harus menentukan aturan (rule) dan pola pembelian produk makanan ringan.

Salah satu metode yang dapat digunakan untuk mengatasi masalah yang berkaitan dengan persediaan adalah dengan menggunakan algoritma Apriori. Algortitma Apriori adalah algoritma pengambilan data dengan assosiatif (association 
Rule) untuk menentukan hubungan assosiatif suatu item. Associaton Rule yang dimaksud dilakukan melalui mekanisme perhitungan support adalah lebih besar dari minimum support dan confidence adalah lebih besar dari minimum confidence. Algoritma Apriori ini akan cocok untuk diterapkan bila terdapat beberapa hubungan item yang ingin dianalisis. Penggunaan algoritma ini, akan memberikan pengetahuan bagi pengguna berupa aturan atau pola pembelian yang telah terjadi. Penerapan Algoritma Apriori, secara umum dibutuhkan struktur data untuk menyimpan candidate frequent itemset untuk suatu iterasi ke k dan untuk menyimpan frequent itemset yang dihasilkan[5]. Ketika membaca tiap item dari seluruh transaksi, selain mendapatkan item-item baru juga dilakukan perhitungan nilai support item-item yang sudah ditemukan, sehingga untuk mendapatkan candidate 1-itemset beserta nilai support-nya cukup membutuhkan satu kali pembacaan data. Algoritma apriori adalah suatu algoritma yang digunakan untuk mining frequent itemset menggunakan aturan asosiasi Boolean. Algoritma aproriari dapat digunakan untuk membantu mengatasi permasalah yang ada pada objek penelitian dalam kaitannya dengan masalah persediaan barang.

Oleh karena itu tujuan dari penelitian ini adalah utuk menerapkan data mining dengan algoritma apriori ke dalam analisis pola pembelian konsumen dan menginterprestasikan pola yang telah dihasilkan menjadi sebuah informasi.

\section{METODE PENELITIAN}

Metode penelitian adalah tahapan yang dilaksanakan sebagai bagian dari kegiatan penelitian dalam upaya untuk mengumpulkan data atau informasi serta melakukan observasi dan investigasi pada data dan informasi tersebut.

\section{A. Data Mining}

Pemrosesan data yang diterapak dalam penelitian ini adalah dengan menggunakan teknik data mining. Data mining yaitu serangkaian proses untuk menggali nilai tambah berupa pengetahuan yang selama ini tidak diketahui secara manual dari suatu kumpulan data[6].

Proses yang menggunakan teknik statistik, matematika, kecerdasan buatan, machine learning untuk mengekstraksi dan mengidentifikasi informasi yang bermanfaat dan pengetahuan yang terkait dari berbagai database besar[7].

\section{Tahan-Tahap Data Mining:}

a. Pembersihan data (data cleaning)

Merupakan proses menghilangkan noise dan data yang tidak konsisten atau data tidak relevan.

b. Integrasi data (data integration)

Merupakan penggabungan data dari berbagai database ke dalam satu database baru.

c. Seleksi Data (Data Selection)

Data yang ada pada database sering kali tidak semuanya dipakai, oleh karena itu hanya data yang sesuai untuk dianalisis yang akan diambil dari database.

d. Data Transformation
Data diubah atau digabung ke dalam format yang sesuai untuk diproses dalam data mining

e. Proses mining.

Merupakan suatu proses utama saat metode diterapkan untuk menemukan pengetahuan berharga dan tersembunyi dari data.

f. Evaluasi pola (pattern evaluation).

Untuk mengidentifikasi pola-pola menarik ke dalam

knowledge based yang ditemukan bermanfaat.

g. Presentasi Pengetahuan (Knowledge Presentation)

Teknik visualisasi dalam mempresentasikan pengetahuan yang dipresentasikan kepada pengguna[8].

Seperti ditunjukan oleh gambar 1 dibawah ini :

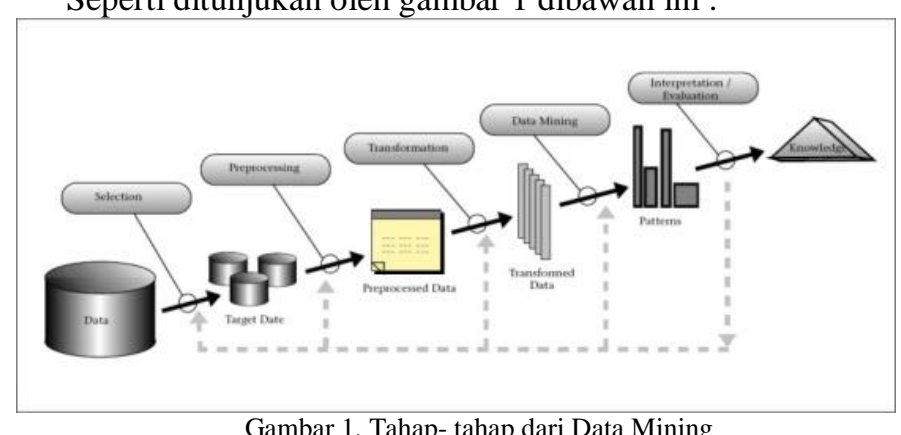

Gambar 1. Tahap- tahap dari Data Mining

\section{B. Penelitian Terdahulu}

Penelitian yang berkaitan dengan penggunaan Algortima Apriori maupun penelitian yang berkaitan dengan penggunaan data mining sudah banyak dilakukan, salah satunya Penelitian dengan judul Implementasi Algoritma Apriori untuk Mencari Asosiasi Barang yang Dijual di E-commerce OrderMas. Penelitian ini menerapkan metode assosiasi dengan algoritma Apriori yang merupakan bagian dari teknik data mining untuk menemukan aturan assosiatif kombinasi antara itemset pada data transaksi penjualan. Perhitungan dilakukan dengan menentukan support dan confidance yang menghasilkan assosiasi rules, yang dapat digunakan untuk menentukan stok barang apa saja yang perlu diperbanyak oleh supplier guna meningkatkan keuntungan antara supplier dan perusahaan[4].

Penelitian lain yang berkaitan dengan data mining dan algoritma apriori adalah penelitian dengan judul data mining dengan algoritma apriori untuk penentuan aturan asosiasi pola pembelian pupuk. Dari hasil penelitiannya dengan penerapan algoritma apriori menentukan kombinasi antar itemset dengan minimum support $20 \%$ dan minimum confidence $75 \%$ ditemukan 6 aturan asosiasi, dimana yang memiliki nilai support dan confidence tertinggi adalah jika konsumen melakukan transaksi pembelian pupuk organik dan pupuk urea secara bersamaan dengan nilai support $60 \%$ dan nilai confidence $86 \%$. Dengan demikian, jika terdapat konsumen membeli pupuk organik, maka kemungkinan konsumen tersebut membeli pupuk urea adalah 86\%[7].

\section{HASIL DAN PEMBAHASAN}

Penelitian ini menghasilkan sebuah sistem berbasis komputer yang dapat memberikan informasi kepada pihak 
pengambil keputusan terkait dengan pola pembelian pelanggan terhadap produk makanan ringan sehingga dalam pengambil keputusan dapat menentukan tindakan yang akan dilakukan dikemudian hari dengan menerapkan algoritma apriori.

Tahapan yang dilakukan dalam pembuatan sistem ini adalah Tahap Identifikasi sistem, Tahap Analisis sistem dan tahap pemrosesan data. Bereikut ini tahap pelaksanaan penelitian yang dilakukan untuk memperoleh Sistem yang sesuai dengan tujuan penelitian.

\section{A. Identifikasi Sistem}

CV. Sukses Mandiri merupakan distributor tunggal dari biskuit AIM dan juga distributor snack dan minuman yang berasal dari Surabaya. Banyak permintaan pembelian dari konsumen membuat perusahaan memiliki data pembelian konsumen yang terus bertambah setiap harinya. Data tersebut disimpan didalam bentuk database yang telah berjalan. Data yang tersimpan sangat banyak dan beragam. Namun untuk menentukan keterkaitan yang ada sangatlah sulit jika harus memilah setiap penjualan kepada konsumen yang ada.

Masalah ini dapat diatasi dengan adanya penambangan data karena semua data penjualan yang ada akan diolah oleh sistem sehingga CV. Sukses Mandiri dapat melihat keterkaitan yang ada. Sistem ini berfungsi sebagai alat bantu untuk CV. Sukses Mandiri dalam menganalisis permintaan pembelian konsumen. Sistem ini menggunakan Data Mining dengan metode Algoritma Apriori. Sistem akan mengolah permintaan pembelian konsumen, data barang harus terlebih dahulu dimiliki dapat dimasukkan pada master barang yang disediakan. Setiap permintaan pembelian konsumen direkap dengan menyimpan juga data barang yang dibeli konsumen, sehingga dapat diketahui pada setiap nota pembelian konsumen terdapat barang apa saja yang dibeli oleh konsumen. Data tersebut akan disimpan dalam database. Semakin banyak data yang disimpan membuat hasil semakin baik.Data pembelian konsumen yang disimpan akan diolah dengan menggunakan teknik apriori.

\section{B. Analisis Sistem}

Data yang akan digunakan untuk penelitian ini adalah data pembelian konsumen dari CV. Sukses Mandiri. Data tersebut diperoleh dari database program yang telah berjalan.

TABLE I. ARtibut TABEl PENJUALAN

\begin{tabular}{|l|l|l|}
\hline \multicolumn{1}{|c|}{ No } & \multicolumn{1}{|c|}{ Nama Atribut } & \multicolumn{1}{c|}{ Keterangan } \\
\hline 1 & tb_produk & Data Produk \\
\hline 2 & tb_supplier & Data Supplier \\
\hline 3 & tb_transaksi & Data Transaksi \\
\hline
\end{tabular}

\section{Pemprosesan Data}

Sebelum data dimasukan ke dalam sistem untuk proses penambangan data, dilakukan pemprosesan awal terlebih dahulu. Pemprosesan tersebut merupakan serangkaian langkah yang sesuai dengan KDD (Knowledge Discovery in Database). Tidak semua langkah dilakukan dalam pemprosesan awal tersebut karena dilihat dari data yang ada. Proses tersebut terdiri dari langkah-langkah berikut:

\section{1) Data Selection (Seleksi Data)}

Proses seleksi data merupakan pemilihan data yang relevan untuk penelitian. Pada database awal terdapat banyak atribut dalam tabel yang tidak diperlukan karena tidak digunakan dalam proses penambangan data.

TABLE II. ARTIBUT UNTUK PENAMBANGAN

\begin{tabular}{|l|l|l|}
\hline No. & Nama Atribut & Keterangan \\
\hline 1 & Quantity & Jumlah Barang yg terjual \\
\hline 2 & Kemasan & Isi barang dalam per karton \\
\hline 3 & Kode_Barang & Kode barang yang telah terjual \\
\hline 4 & Nama_Barang & Nama item yang terjual \\
\hline 5 & Harga_Satuan & Satuan item yang terjual \\
\hline 6 & Disc & Diskon penjualan per item \\
\hline 7 & Jumlah_Harga & Total harga dikali jumlah item yang terjual \\
\hline
\end{tabular}

\section{2) Data Cleaning (Pembersihan Data)}

Proses pembersihan data merupakan langkah pertama yang harus dilakukan. Dari data mentah yang ada dilakukan pembersihan dari data yang tidak relevan. Namun dalam data penjualan ini tidak dilakukan pembersihan karena data mentah tersebut dapat digunakan seluruhnya.

\section{3) Data Integration (Integrasi Data)}

Proses integrasi data merupakan penggabungan data dari beberapa sumber. Disini yang diperlukan untuk penambangan data adalah data pembelian dari Pabrik dan data Penjualan kepada Konsumen. Untuk itu diperlukan penggabungan terlebih dahulu dari rekap data penjualan tersebut.

TABLE III. ARTIBUT PENJULAN DARI PABRIK

\begin{tabular}{|l|l|l|}
\hline No. & Nama Atribut & \multicolumn{1}{c|}{ Keterangan } \\
\hline 1 & Quantity & Jumlah Barang yang dibeli dari Pabrik \\
\hline 2 & Kemasan & Isi barang dalam per karton \\
\hline 3 & Kode_Barang & Kode barang yang telah dibeli dari Pabrik \\
\hline 4 & Nama_Barang & Nama item yang telah dibeli dari Pabrik \\
\hline 5 & Harga_Satuan & Satuan item yang telah dibeli dari Pabrik \\
\hline 6 & Jumlah_Harga & $\begin{array}{l}\text { Total harga dikali jumlah item yang telah } \\
\text { dibeli dari Pabrik }\end{array}$ \\
\hline
\end{tabular}

TABLE IV.

ARTIBUT PENJULAN KONSUMEN

\begin{tabular}{|l|l|l|}
\hline No. & Nama Atribut & \multicolumn{1}{c|}{ Keterangan } \\
\hline 1 & noFaktur & Nomor faktur Penjualan ke Konsumen \\
\hline 2 & kodeBarang & Kode barang yang telah dijual ke konsumen \\
\hline 3 & namaBarang & Nama barang yang telah dijual ke konsumen \\
\hline 4 & Satuan & Satuan item yang telah dijual ke konsumen \\
\hline 5 & hargaJual & $\begin{array}{l}\text { Harga jual untuk barang yang dibeli } \\
\text { konsumen }\end{array}$ \\
\hline 6 & Quantity & $\begin{array}{l}\text { Jumlah barang yang telah dijual ke } \\
\text { konsumen }\end{array}$ \\
\hline 7 & Jumlah & Total keseluruhan barang \\
\hline
\end{tabular}

Berdasarkan tabel III. Dan IV, akan dilakukan penggabungan menjadi satu tabel untuk diolah. Tabel penggabungan tersebut merupakan tabel penjualan_det. 
4) Data Transformation (Transformasi Data)

Proses transformasi data merupakan proses pengubahan data menjadi bentuk atau satuan yang tepat untuk ditambang. Pada data yang dimiliki tidak memerlukan proses transformasi karena tidak memiliki data continue karena data yang diambil adalah hasil masukkan program sehingga tidak ada data kosong.

\section{5) Proses Mining}

Proses penambangan data merupakan proses pengolahan data yang telah didapat dari pemrosesan data.

\section{6) Pattern Evaluation (Evaluasi Pola)}

Proses evaluasi pola akan dilakukan dengan penggunaan lift ratio untuk mengukur seberapa penting aturan yang telah didapat dari program. Nilai ini akan menunjukkan kevalidan informasi apakah barang A dibeli secara bersamaan dengan barang B, yang diperoleh dari hasil perhitungan support dan confidence.

$$
\text { Lift Ratio }=\frac{\operatorname{Support}(A \cap B)}{\operatorname{Support}(A) * \operatorname{Support}(B)}
$$

\section{Langkah-langkah Algoritma Apriori :}

\section{1) Analisis Pola Frekuensi Tinggi}

Tahap ini mencari kombinasi item yang memenuhi syarat minimum dari nilai support dalam database. Nilai support sebuah item diperoleh dengan rumus berikut:

$$
\operatorname{upport}(\mathrm{A})=\frac{\text { Jumlah Transaksi mengandung } \mathrm{A}}{\text { Total Transaksi }}
$$

Sedangkan nilai support dari 2 item diperoleh dari rumus berikut :

$$
\operatorname{upport}(\mathrm{A} U \mathrm{~B})=\frac{\text { Jumlah Transaksi mengandung A dan B }}{\text { Transaksi otal }} \ldots
$$

\section{2) Pembentukan Aturan Asosiasi}

Setelah semua pola frekuensi tinggi ditemukan, barulah dicari aturan assossiatif yang memenuhi syarat minimum untuk confidence dengan menghitung confidence aturan assosiatif A -> B. Nilai confidence dari aturan A->B diperoleh dari rumus:

Confidence $=P(B \mid A)=\frac{\text { Jumlah Transaksi mengandung A dan } \mathrm{B}}{\text { Jumlah Transaksi mengandung } \mathrm{A}}$.

Berdasarkan langkah-langkah tersebut di atas, berikut ini merupakan contoh transaksinya:

Inisial Barang yang ada di CV. Sukses Mandiri

A : Square Puff

B: GabingSuperbis

C : Roasted Corn

D : Choco Cream

E : Crispy Crackers
TABLE V. TABEL TRANSAKSI YANG ADA DI CV. SUKSES MANDIRI

\begin{tabular}{|c|l|}
\hline Transaksi & Item yang terjual \\
\hline 1 & D, E, C \\
\hline 2 & C, A \\
\hline 3 & C, B, D \\
\hline 4 & A, C, E, D \\
\hline 5 & E, D \\
\hline 6 & E, C, B \\
\hline 7 & B, D, A \\
\hline
\end{tabular}

Proses yang dilakukan sebagai berikut:

1. Pemisahan setiap transaksi item yang Terjual

TABEL VI. ITEM YANG TERJUAL

\begin{tabular}{|c|}
\hline Item yang terjual \\
\hline $\mathrm{A}$ \\
\hline $\mathrm{B}$ \\
\hline $\mathrm{C}$ \\
\hline $\mathrm{D}$ \\
\hline $\mathrm{E}$ \\
\hline
\end{tabular}

2. Kemudian buat tabel transaksi yang ada di CV. Sukses Mandiri seperti dpada tabel VI

TABEL VII. TRANSAKSI MASING-MASING PENJUALAN BARANG/KARTON

\begin{tabular}{|l|l|l|l|l|l|}
\hline \multicolumn{1}{|c|}{ Transaksi } & A & B & C & D & E \\
\hline 1 & 0 & 0 & 1 & 1 & 1 \\
\hline 2 & 1 & 0 & 1 & 0 & 0 \\
\hline 3 & 0 & 1 & 1 & 1 & 0 \\
\hline 4 & 1 & 0 & 1 & 1 & 1 \\
\hline 5 & 0 & 0 & 0 & 1 & 1 \\
\hline 6 & 0 & 1 & 1 & 0 & 1 \\
\hline 7 & 1 & 1 & 0 & 1 & 0 \\
\hline$\sum$ & 3 & 3 & 5 & 5 & 4 \\
\hline
\end{tabular}

\section{Tentukan $\Phi$}

Misalkan kita tentukan $\Phi=3$, maka kita dapat menentukan frekuen itemset. Dari tabel di atas diketahui total $\Phi$ untuk transaksi $\mathrm{k}=1$, semuanya lebih besardari $\Phi$. Maka:F1 $=\{\{\mathrm{A}\}$, $\{B\},\{C\},\{D\},\{E\}\}$

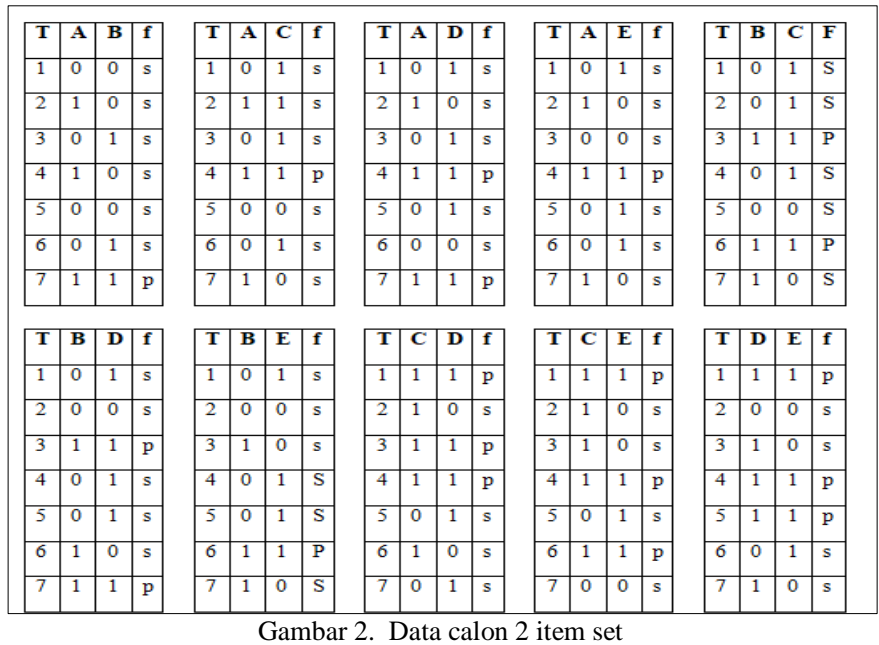


Untuk $\mathrm{k}=2$ (2 unsur), diperlukan tabel untuk tiap-tiap pasang item. Himpunan yang mungkin terbentuk adalah: $\{A, B\},\{A, C\},\{A, D\},\{A, E\},\{B, C\},\{B, D\},\{B, E\},\{C, D\}$, $\{\mathrm{C}, \mathrm{E}\},\{\mathrm{D}, \mathrm{E}\}$.

Dari gambar 2 di atas, $P$ artinya item-item yang dijual bersamaan, sedangkan $S$ berarti tidak ada item yang dijual bersamaan atau tidak terjadi transaksi. $\Sigma$ melambangkan jumlah Frekuensi item set. Jumlah frekuensi item set harus lebih besar atau sama dengan jumlah Frekuensi item set $(\Sigma>=$ $\Phi)$.Dari tabel diatas, maka didapat: $\mathrm{F} 2=$ $\{\{\mathrm{C}, \mathrm{D}\},\{\mathrm{C}, \mathrm{E}\},\{\mathrm{D}, \mathrm{E}\}\}$

Kombinasi dari itemset dalam F2, dapat kita gabungkan menjadi calon 3-itemset. Itemset-itemset yang dapat digabungkan adalah itemset-itemset yang memiliki kesamaan dalam k-1 item pertama.

Untuk $\mathrm{k}=3$ (3 unsur), himpunan yang mungkin terbentuk adalah: $\{\mathrm{C}, \mathrm{D}, \mathrm{E}\}$

TABEL VIII. ITEM TRANSAKSI TERGABUNG

\begin{tabular}{|l|l|l|l|l|}
\hline T & $\mathbf{C}$ & $\mathbf{D}$ & $\mathbf{E}$ & $\mathbf{F}$ \\
\hline 1 & 1 & 1 & 1 & $\mathrm{P}$ \\
\hline 2 & 1 & 0 & 0 & $\mathrm{~S}$ \\
\hline 3 & 1 & 1 & 0 & $\mathrm{~S}$ \\
\hline 4 & 1 & 1 & 1 & $\mathrm{P}$ \\
\hline $\mathbf{T}$ & $\mathbf{C}$ & $\mathbf{D}$ & $\mathbf{E}$ & $\mathbf{F}$ \\
\hline 5 & 0 & 1 & 1 & $\mathrm{~S}$ \\
\hline 6 & 1 & 0 & 1 & $\mathrm{~S}$ \\
\hline 7 & 0 & 1 & 0 & $\mathrm{~S}$ \\
\hline & & & 2 \\
\cline { 3 - 5 }
\end{tabular}

Dari VIII, didapat $\mathrm{F} 3=\{\}$, karena tidak ada $\Sigma>=\Phi$ sehingga F4, F5, F6 dan F7 juga merupakan himpunan kosong.

4. Tentukan (ss-s) sebagai antecedent dan s sebagai consequent dari Fk yang telah didapat Pada F2 didapat himpunan $\mathrm{F} 2=\{\{\mathrm{C}, \mathrm{D}\},\{\mathrm{C}, \mathrm{E}\},\{\mathrm{D}, \mathrm{E}\}\}$

Maka dapat disusun:

- Untuk $\{\mathrm{C}, \mathrm{D}\}$ :

- Jika (ss-s) $=$ C, Jika $s=D$, Maka $\rightarrow$ If buy C then buy D

- Jika (ss-s) $=$ D, Jika s $=$ C, Maka $\rightarrow$ If buy D then buy C

- Untuk $\{\mathrm{C}, \mathrm{E}\}$ :

- Jika $($ ss-s) $=$ C, Jika s $=$ E, Maka $\rightarrow$ If buy C then buy E

- Jika (ss-s) $=$ E, Jika s $=$ C, Maka $\rightarrow$ If buy E then buy C

- Untuk $\{\mathrm{D}, \mathrm{E}\}$ :

- Jika (ss-s) $=$ D, Jika s $=$ E, Maka $\rightarrow$ If buy D then buy E

- Jika (ss-s) $=$ E, Jika s $=$ D, Maka $\rightarrow$ If buy E then buy D

5. Dari langkah di atas, kita mendapatkan 6 rule yang dapat digunakan, yaitu:

- If buy $\mathrm{C}$ then buy $\mathrm{D}$

- If buy D then buy C

- If buy $\mathrm{C}$ then buy $\mathrm{E}$

- If buy $\mathrm{E}$ then buy $\mathrm{C}$
- If buy $\mathrm{D}$ then buy $\mathrm{E}$

- If buy $\mathrm{E}$ then buy $\mathrm{D}$

6. Hitung support dan confidence.

Hasil hitung support dan confidence dapat dilihat pada tabel

TABEL IX. HITUNG SUPPORT DAN CONFIDENCE

\begin{tabular}{|l|l|c|}
\hline $\begin{array}{c}\text { If antecedent then } \\
\text { consequent }\end{array}$ & Support & Confidence \\
\hline If buy C then buy D & $(3 / 7) \times 100 \%=42,86 \%$ & $(3 / 5) \times 100 \%=60 \%$ \\
\hline If buy D then buy C & $(3 / 7) \times 100 \%=42,86 \%$ & $(3 / 5) \times 100 \%=60 \%$ \\
\hline If buy C then buy E & $(3 / 7) \times 100 \%=42,86 \%$ & $(3 / 5) \times 100 \%=60 \%$ \\
\hline If buy E then buy C & $(3 / 7) \times 100 \%=42,86 \%$ & $(3 / 4) \times 100 \%=75 \%$ \\
\hline If buy D then buy E & $(3 / 7) \times 100 \%=42,86 \%$ & $(3 / 5) \times 100 \%=60 \%$ \\
\hline If buy E then buy D & $(3 / 7) \times 100 \%=42,86 \%$ & $(3 / 4) \times 100 \%=75 \%$ \\
\hline
\end{tabular}

7. Setelah di dapat support dan confidence untuk masingmasing kandidat,lakukan perkalian antara support dan confidence, dimana confidence-nya diambil $70 \%$ ke atas, sehingga di dapat tabel sbb:

TABEL $\quad \mathrm{X}$. PERKALIAN SUPPORT DAN CONFIDENCE

\begin{tabular}{|l|l|l|l|}
\hline $\begin{array}{l}\text { If antecedent then } \\
\text { consequent }\end{array}$ & Support & Confidence & $\begin{array}{l}\text { Support } \\
\text { Confidence }\end{array}$ \\
\hline If buy E then buy C & $42,86 \%$ & $75 \%$ & 0.32145 \\
\hline If buy E then buy D & $42,86 \%$ & $75 \%$ & 0.32145 \\
\hline
\end{tabular}

8. Setelah didapat hasil perkalian antara support dan confidence, pilihlah yang hasil perkaliannya paling besar. Hasil paling besar dari perkalian perkalian tersebut merupakan rule yang dipakai pada saat menjual. Karena hasil perkalian dari ke-2 penjualan di atas bernilai sama, maka semuanya bisa dijadikan rule.

\section{Diagram Use Case}

Pada sistem ini akan ada 1 pengguna. Kegiatan yang dapat dilakukan adalah menginput data, melihat histori penjualan, mencari rule penjualan, dan melihat hasil apriori. Dari kegiatan yang dapat dilakukan, terdapat 1 kegiatan yang terdapat keterangan depands on yang artinya baru dapat dilakukan setelah kegiatan sebelumnya dikerjakan.

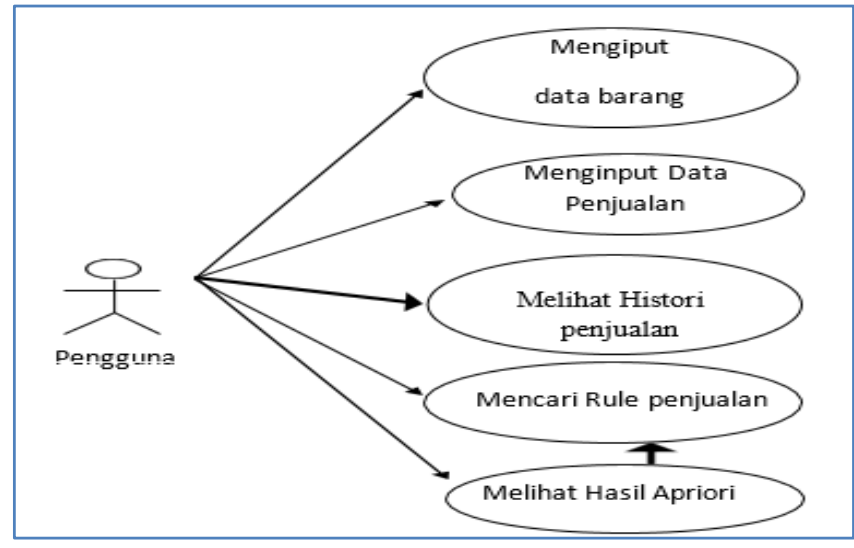

Gambar 3. Diagram Use Case 
Gambar 3 menjelaskan bahwa pengguna dalam sistem akan menginput data barang dan data penjualan. Hasil dari penginputan tersebut dimana pengguna akan dapat melihat histori penjualan, mencari rule penjualan, serta hasil dari metode apriori yang diinginkan.

\section{E. Antar Muka Sistem}

Antar muka (Interface) berfungsi sebagai penghubung antara pengguna (user) dengan System yang dibangun. Berikut ini antarmuka sistem yang dibangun dalam penelitian ini.

Data Barang merupakan data yang muncul ketika menekan tombol barang Halaman ini digunakan untuk memasukan data barang baru atau melakukan edit untuk barang yang sudah ada. Barang disini dapat digunakan untuk melakukan penjualan. Dalam data barang ini, terdapat kode barang yang telah otomatis dari program, kemudian nama barang, jumlah item barang, satuan, dan harga jual satuan yang dapat diisi oleh pengguna. Gambar 4 menunjukan interface untuk form data barang.

\section{Isi Data Barang}

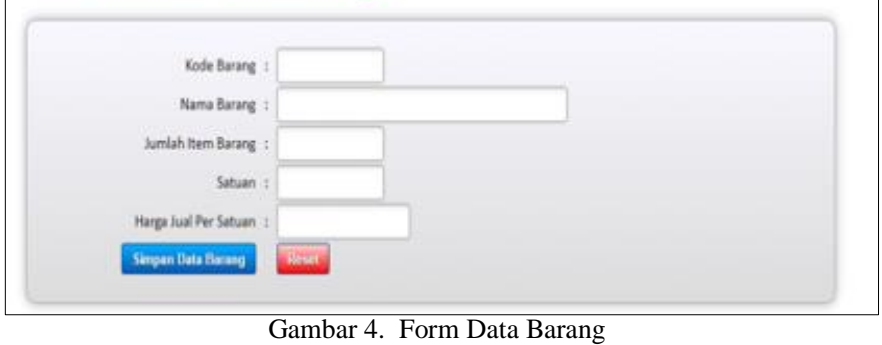

Data penjualan merupakan data yang untuk menambahkan data penjualan. Data penjualan digunakan untuk analisis dengan algoritma apriori. Dalam data penjualan ini terdapat ID Pelanggan, nomor faktur, kode barang, nama barang, tanggal jual, satuan, jumlah item, harga jual satuan, jumlah dibayar. Kemudian data disimpan untuk proses berikutnya. Gambar 5 menunjukan antarmuka untuk form data Penjualan.

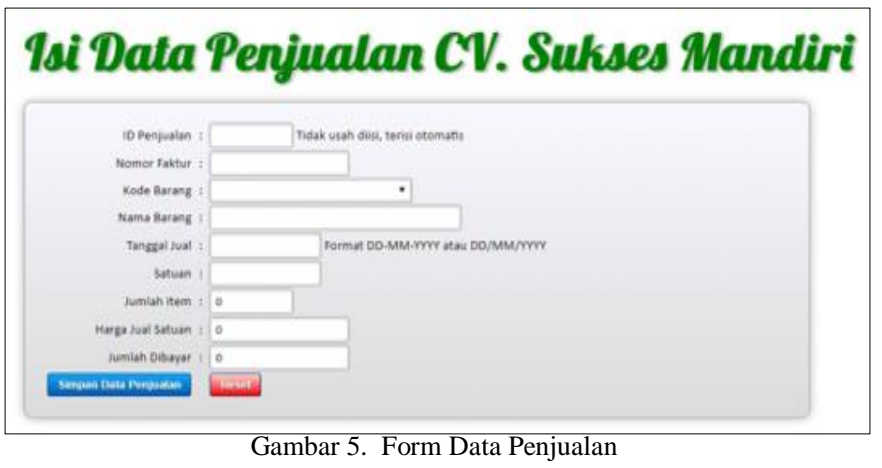

Peringkasan transaksi penjualan merupakan proses peringkasan untuk membentuk tabel setiap transaksi dalam satu record tersendiri. Transaksi ini dijalankan dengan menekan tombol Ringkas Transaksi. Setelah menekan tombol tersebut maka diperoleh hasil Jumlah Record Penjualan sebanyak 1532 record dan Jumlah Faktur Transaksi Penjualan sebanyak 410 transaksi. Gambar 6 dan 7 menunjukan antarmuka untuk Peringkasan Transaksi Penjualan.

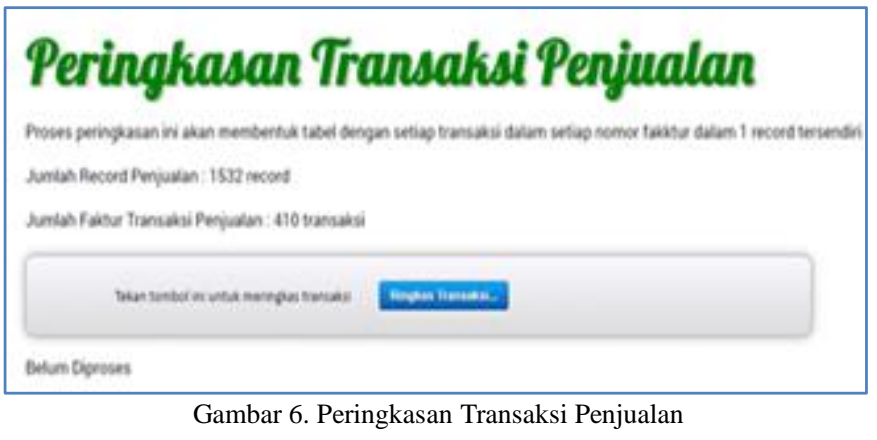

\section{Ringkasan Transaksi Penjualan}

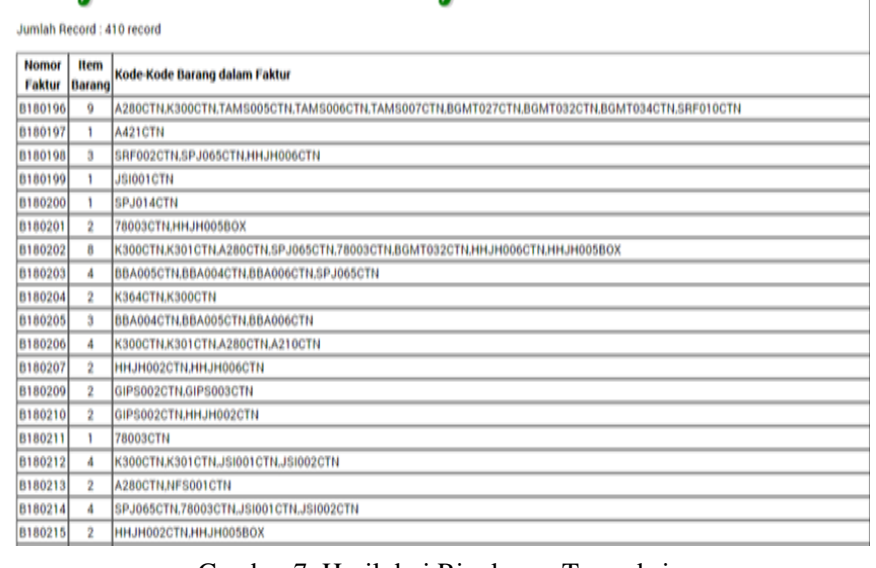

Gambar 7. Hasil dari Ringkasan Transaksi

\section{F. Pengujian Program}

Pengujian sistem dilakukan untuk proses uji coba sistem yang akan dijalankan pada aplikasi data mining dengan menggunakan algoritma apriori. Dalam penelitian ini pembahasan mengenai pengujian yang telah dilakukan pada sistem dan evaluasi dari hasil yang dikeluarkan sistem. Dari pengujian ini dapat diketahui bagaimana perbedaan pola data yang dihasilkan. Pengujian dilakukan dengan memasukkan :

Jumlah record $=1532$ record

Transaksi penjualan $=410$ transaksi

Minimum itemset $=3$ itemset

Minimum support $=10 \%$.

Berdasarkan hasil pengujian di atas, dapat ditarik kesimpulan bahwa nilai support dan confidence dapat digunakan untuk promosi penjualan dengan penentuan diskon atau bonus. Rule yang mengandung support yang tinggi adalah penjualan barang yang laku, yang dapat disimpulkan dari banyak terdapat barang tersebut dalam transaksi yang ada dan sebaliknya. Dengan begitu dapat membantu dalam membuat pemecahan masalah. Barang yang tidak muncul dalam minimum support dapat digunakan sebagai bonus pembelian barang yang memiliki support lebih tinggi sehingga barang yang memiliki support kecil dapat terbuang dari gudang karena tidak laku pada penjualan. 
TABEL XI. HASIL PENGUJIAN PROGRAM

\begin{tabular}{|c|c|c|c|c|}
\hline Itemset & $\begin{array}{l}\text { Jumlah } \\
\text { Record }\end{array}$ & Kode Barang & $\begin{array}{l}\text { Jumlah } \\
\text { Item }\end{array}$ & $\begin{array}{c}\text { Support } \\
(\%)\end{array}$ \\
\hline \multirow{6}{*}{1 Itemset } & \multirow{6}{*}{6 Record } & 78003CTN & 74 & $18,05 \%$ \\
\hline & & SPJ06CTN & 71 & $17.32 \%$ \\
\hline & & JSI001CTN & 65 & $15,85 \%$ \\
\hline & & JSI002CTN & 61 & $14,88 \%$ \\
\hline & & JSI004CTN & 46 & $11,22 \%$ \\
\hline & & HHJH002CTN & 62 & $10,24 \%$ \\
\hline \multirow[t]{6}{*}{2 Itemset } & \multirow[t]{6}{*}{6 Record } & $\begin{array}{l}\text { JSI001CTN, } \\
\text { JSI002CTN }\end{array}$ & 13 & $17 \%$ \\
\hline & & $\begin{array}{l}\text { 78003CTN, } \\
\text { JSI001CTN }\end{array}$ & 6 & $16 \%$ \\
\hline & & $\begin{array}{l}\text { HHJH002CTN, } \\
\text { JSI002CTN }\end{array}$ & 14 & $13 \%$ \\
\hline & & $\begin{array}{l}\text { JSI001CTN, } \\
\text { JSI004CTN }\end{array}$ & 6 & $13 \%$ \\
\hline & & $\begin{array}{l}\text { JSI002CTN, } \\
\text { JSI004CTN }\end{array}$ & 14 & $12 \%$ \\
\hline & & $\begin{array}{l}\text { JSI002CTN, } \\
\text { SPJ065CTN }\end{array}$ & 14 & $10 \%$ \\
\hline \multirow{6}{*}{3 Itemset } & \multirow{6}{*}{6 Record } & $\begin{array}{l}\text { JSI001CTN,JSI99 } \\
\text { 4CTN,SPJ065CT } \\
\mathrm{N}\end{array}$ & 8 & $17,19 \%$ \\
\hline & & $\begin{array}{l}\text { 78003CTN,JSI00 } \\
\text { 1CTN,SPJ065CT } \\
\mathrm{N}\end{array}$ & 11 & $16,71 \%$ \\
\hline & & $\begin{array}{l}\text { JSI001CTN,JSI00 } \\
4 \text { CTN,JSI004CT } \\
\mathrm{N}\end{array}$ & 11 & $13,20 \%$ \\
\hline & & $\begin{array}{l}\text { HHJH002CTN,JS } \\
\text { I002CTN,JSI004 } \\
\text { CTN }\end{array}$ & 4 & $12,02 \%$ \\
\hline & & $\begin{array}{l}\text { JSI001CTN,JSI00 } \\
\text { 2CTN,SPJ065CT } \\
\mathrm{N}\end{array}$ & 15 & $11,94 \%$ \\
\hline & & $\begin{array}{l}\text { HHJH002CTN,JS } \\
\text { I002CTN,JSI004 } \\
\text { CTN }\end{array}$ & 14 & $10,87 \%$ \\
\hline
\end{tabular}

Berdasarkan hasil yang ditunjukkan pada tabel XI dapat diketahui bahwa terdapat 6 itemset barang yang paling sering dibeli oleh konsumen. Adapun item barang tersebut adalah 78003CTN (Mie Tek-Tek), HHJH002CTN (Hoka-Hoka Jelly Es Potong), JSI001CTN (Hepillo Ayam Bawang), JSI002CTN (Hepillo Barbeque), JSI004 (Hepillo Sapi Panggang), dan SPJ065CTN (Wafer Kita 2 Rasa). Jika berdasarkan perhitungan nilai support dengan menggunakan 3 itemset maka diperoleh hasil sebagai berikut :

a. Jika membeli Mie Tek-Tek, dan Hepilo Ayam maka harus membeli Wafer Kita 2 Rasa dengan minimum Support 16,71\% dan Confidence $11 \%$.

b. Jika membeli Hoka-hoka Jelly Box, maka harus membeli Hepillo Barbeque dengan minimum Support 12,02\% dan Confidence $4 \%$. c. Jika membeli Hoka-hoka Jelly Box dan Hepillo Barbeque maka harus membeli Wafer Kita 2 Rasa dengan minimum Support 10,87\% dan Confidence $14 \%$

d. Jika membeli Hepilo Ayam dan Hepillo Barbeque maka harus membeli Wafer kita 2 Rasa dengan Minimum Support 11,94\% dan Confidence $15 \%$

e. Jika membeli Hepillo Ayam dan Hepillo Barbeque maka harus membeli Hepillo Sapi Panggang dengan Minimum Supprot 13,20\% dan Confidence $11 \%$

f. Jika membeli Hepilo Ayam dan Hepillo Sapi Panggang maka harus membeli Wafer kita 2 Rasa dengan minimum Support $17,19 \%$ dan Confidence $8 \%$.

\section{PENUTUP}

Dari hasil penelitian yang telah dilakukan, maka dapat diperoleh beberapa kesimpulan bahwa Algoritma Apriori dapat diimplementasikan untuk mendapatkan pola penjualan dari histori yang ada. Selain itu berdasarkan hasil pola penjualan dapat memberikan pengetahuan bagi pengguna untuk mengoptimalkan penjualan, semakin besar support yang muncul pada output maka barang tersebut paling laku untuk dijual.

Untuk penelitian lanjutan, peneliti dapat memberikan saran untuk memperbanyak jumlah data penjualan sehingga dapat mendapatkan hasil dengan persentase yang lebih tinggi. Disamping itu juga data penjualan yang dimasukkan dapat dibuat lebih universal sehingga dapat digunakan untuk datadata penjualan selain penjualan biskuit dan snack.

\section{REFERENSI}

[1] K. P. RI, "Industri Makanan dan Minuman Masih Jadi Andalan," https://kemenperin.go.id, Jakarta, 23-Nov-2017.

[2] S. N. Indonesia, "Biskuit," SNI, vol. 2973, p. 2011, 2011.

[3] Petrus Dabu, "Tahun 2018, industri makanan minuman diperkirakan tumbuh 10\%," https://industri.kontan.co.id, Jakarta, 30-Jan-2018.

[4] A. S. Moh.Sholik, "Implementasi Algoritma Apriori untuk Mencari Asosiasi Barang yang Dijual di E-commerce OrderMas," Techno.COM, vol. 17, no. 2, pp. 158-170, 2018.

[5] F. A. Sianturi, "Penerapan Algoritma Apriori Untuk Penentuan Tingkat Pesanan,” J. Mantik Penusa, vol. 1, no. 1, pp. 50-57, 2018.

[6] A. F. Hadi, “Analisis Data Mining Untuk Menentukan Variabel Variabel Yang Mempengaruhi Kelayakan Kredit Kepemilikan Rumah Menggunakan Teknik Klasifikasi,"KomTekInfo, vol. 4, no. 1, pp. 108115, 2017.

[7] L. S. L. Koko Handoko, "Data Mining Pada Jumlah Penumpang Menggunakan Metode Clustering," in SNISTEK, 2018, pp. 97-102.

[8] K. Tampubolon, H. Saragih, B. Reza, K. Epicentrum, and A. Asosiasi, "Implementasi Data Mining Algoritma Apriori pada sistem persediaan alat-alat kesehatan," Inf. dan Teknol. Ilm., vol. 1, no. 1, pp. 93-106, 2013. 